\title{
Effects of Entrepreneurial Orientations on Organizational Learning in a Manufacturing Firm in Nigeria
}

\author{
Eugene Ofoegbu Onyema ${ }^{1}$ \\ ${ }^{1}$ Department of Business Administration, Ajayi Crowther University, Oyo, Nigeria \\ Correspondence: Eugene Ofoegbu Onyema, Ph.D., Department of Business Administration, Ajayi Crowther \\ University, Oyo, Oyo State, P.M.B 1066, Nigeria. Tel: 234-70-8161-8555. E-mail: onyemaofoegbu@gmail.com
}

Received: December 9, 2013

Accepted: January 26, $2014 \quad$ Online Published: March 5, 2014

doi:10.5430/ijba.v5n2p94

URL: http://dx.doi.org/10.5430/ijba.v5n2p94

\begin{abstract}
The concept of entrepreneur orientation and entrepreneurship has always been spoken of as being key factor in organisational learning and performance. The contention has been that entrepreneurial firms take more risks than other types of firms. An objective of the study therefore, is to determine the true position and appropriateness of the above view The study intends also to ascertain whether risk -taking behavior, proactiveness and competitive aggressiveness jointly and independently predict entrepreneurial innovativeness and the relationships of these variables. The data for the study was collected through questionnaire administered on different categories of staff of Unilever Nig. Plc. The data collected was analysed using multiple regression, frequency counts, percentages and Pearson's correlation analysis. The result of the study indicated that entrepreneurial orientation as measured by risk taking behaviour, proactiveness and competitive aggressiveness has positive and significant impact on organizational learning. The conclusion from the study is that the enterprises especially small and medium scale ones, must learn and apply knowledge of such learning to adjustment strategies in order to take advantage of emerging opportunities. It is recommended that given the increasing volatility of enterprise operating environment enterprises need to continually increase their coping ability through learning.
\end{abstract}

Keywords: entrepreneurial orientation, proactiveness, competitive aggressiveness, organisational learning and performance

\section{Introduction}

The concept of entrepreneurship and organizational learning are two topical issues in the business arena today. The role of entrepreneurship on organizational learning and its concomitant impact on organizational performance has also attracted attention. Entrepreneurship is a hot topic these days. It features frequently in discussions among policy makers, academic researchers and in more mundane talk shows (Cotis 2007)

It has been equally contended that entrepreneurship is good and should be encouraged. There is a growing scientific evidence that entrepreneurial activities are important matter for employment productivity and ultimately economic growth (Cotis 2007) There is a widely - held belief that there exists a positive link between entrepreneurship and economic growth (Deakins \& Fieel 2009). Entrepreneurship is a process by which individuals pursue opportunities without regard to the resources they control (Stevenson and Jarillo 1997). According to Reynolds and White (1997) creativity is indeed an important element in the entrepreneurial process and for Curran and Stanworth (1989) entrepreneurship refers to the creation of new economic entity centred on a novel product or service or at the very least, one which differs significantly from products or services offered elsewhere in the market.

Among the foremost proponents of the positive link between entrepreneurship and economic growth is the highly influential annual Global Entrepreneurial Monitor GEM (2005). The clearest link between innovation and entrepreneurship or innovation and small firms may arguably be traced to Schumpeter (1934). The fact is however, that entrepreneurship, intrapreneurship and entrepreneurial interplay results from three elements situated in a given environment Kao (1989). Indeed three approaches to entrepreneurship have been identified (a) the contribution of economic writers and theorists on the role of the entrepreneur in economic development and the application of economic theory.(b) psychological trait on personality characteristics of the entrepreneur.(c) a social behavioral approach which stresses the influence of the social environment as well as personality traits. 
Entrepreneurship has also been viewed from different perspectives. For Sechos and Mair (2005) Social entrepreneurs can refer to many types of activities, organization and people. Social enterpre3neurship is a concept that covers the individual motivation and leadership behind the pursuit of social objectives. Furthermore, Cheverton (2006) introduces the concept of political entrepreneurship which according to him, is about knowing in the first place that are there questions to be asked and then being able to pilot a course through the potentially troubled waters ahead. It is indeed helpful to conceptualise the entrepreneur as a risk manager as this identifies one of the key concepts of understanding the process of entrepreneurship (Dieakins \&Fieel 2005)

The application of organizational learning theories in small and medium enterprises (SMEs) helps to explain those that are "Innovative" companied to those that are not stable (ZLanget et al 2006 and Wyerat at 2000). To be successful, entrepreneurs must be able to learn from decisions, from mistakes, from experience and from their network. It is a process that is characterized by significant and critical learning events (Deakins and Freel 2005). The ability of the entrepreneurs to learn is crucial to their behavior and ability to succeed (Deakins and Freel 2005)

Despite the general opinion of the effect of entrepreneurship on organizational learning and economic growth, there are those who differ. For Boettke and Coyne (2002), entrepreneurship is an omnipresent aspect of human action such that all individuals are entrepreneurs, entrepreneurship cannot be the cause of economic development. Instead we must look at the rules of the game and determine the behaviours which those incentives encourage and discourage. Despite the determined efforts of the proponents of the positive link between entrepreneurship organizational learning and economic growth and the generally confirmatory conclusions they reach. Wennekers and Ihurick (1999) noted that the importance of institutions for the development of entrepreneurship is paramount and deserves for the standy. The clearage of opinion between the proponents and opponents of the sole of entrepreneurship on organization has lent chenece to this study. It is equally noteworthy that in recent years the value of entrepreneurs has increased signaling the need for entrepreneurial orientation on organizational learning. It has been contended that entrepreneurs and intrapreneurs in manufacturing firm in Nigeria are not efficient in applying entrepreneurial orientations in the enhancement of their performance.

Given the above scenario and bifurcations of opinions on the effect of entrepreneurship orientation an organizational learning the study looks at the importance of entrepreneurial orientation in a manufacturing firm in Nigeria. It also intended to ascertain low entrepreneurial skills could be enhanced through and by organizational learning and its consequent effects and importance on the operations of firms in Nigeria.

\section{Objectives of This Study}

The fundamental objective of the study is to ascertain the effects of entrepreneurial orientation on organizational learning. Other objectives include, to identify whether there is a significant relationship between proactiveness and organizational learning; to examine whether risk taking, proactivity and competitive aggressiveness will jointly and independently predict organizational learning; to find out whether there is a significant relationship between proactivity and organizational learning; to ascertain the main and interactive effect of risk taking and proactivity on organizational learning and to find out whether there is a significant relationship between competitive aggressiveness and organizational learning.

\section{Study Questions}

Certain questions were posed apriori which the study was meant to answer. The questions include the following

a. Is there a significant relationship between risk taking and organizational learning?

b. Is there a significant relationship between proactiveness and organizational learning?

c. Can risk taking behaviour, proactivenes and competitiveness, aggressiveness jointly or independently predict organizational learning?

d. Could there be a significant relationships between aggressiveness and organizational learning?

e. Will there be main and interactive effect of risk taking and proactiveness on organizational learning?

\section{Literature Review}

It is customary in a study like this to review the literature on the subject matter. Entrepreneurship orientation opines that entrepreneurial firms and organisations are inclined to take more risks than other firms especially in volatile and unpredictable business situations. A successful entrepreneur is one who is able to identify, assess and evaluate the importance of the risk (Deakins \& Freel 2009). 
For Coven and Slevin (2006) entrepreneurial orientation is better measured by summing up "the extent to which top managers are inclined to take business related risks which could put the firm in a position of comparative advantage. Change has been viewed as an accompaniment to entrepreneurship because the pace of change provides opportunities and the entrepreneur chooses which one to back" (Simon \& Hitt 2003). Obviously, it is the ability to make this choice and the act of making it right that differentiates the risk taker (entrepreneur) from the non-risk taker.

According to Monolova and Yan (2002) the environment for entrepreneurial activity was hostile and entrepreneurial responses included the characteristics of "short term" orientation informed networking, opportunism and surplus extraction. Proactivity no doubt is of immense benefit to a firm because being there first gives it an advantage of setting the pace and reaping the fruit. Sales growth and profitability are positively and significantly related to proactivity (Zahra 1996, Lumpkin and Dess 2001). Proactive behavior would be strongly linked to firms performance in an uncertain business environment support for such a view comes from Miller and Friesen (1992) who contend that munificent environments promote proactive behavior since growing markets tend to be characterized by strategic opportunities.

According (Liebarman and Montgomery 1988) firms that are proactive in their orientation are able to take advantage of the very many opportunities brought about by the situation and by so doing establish themselves as to industry leaders. However, Lumpkin \& Dess (2001) appear to disagree with the above view. They argue that hostile environments would force organizations to abandon proactive behaviours to be able to conserve then limited resources.

It has been argued that dynamic environments tend to give rise to stronger link between organizational risk taking and a firm's performance. Evidence of this has come from the work of (Corin \& Stevin 1991, miller1983, Khandwalla 1977). What seems to emerge from the above views is that organizational risk taking is positively correlated to a firm's performance. It has been argued that organizational innovativeness is positively related to superior performance (Hult et al 2004 Basin 2004, Zhao 2006). However, Goll and Rasheed (1997) observe that lack of resources lead firms to avoid excessive risk taking. A firm's performance may be affected by the interaction between entrepreneurial orientation and key characteristics of the external environment (Lumpkin \& Decs 2001). A view has been expressed that organizations which operate under volatile and uncertain environment are more likely to be more innovative than firms that operate under stable environment (Zahra 1993, Miller 1988, Miller 1983).

To survive in a competitive market firms must be entrepreneurial. They must adapt decisions consistent with entrepreneurial behavior (Hile and Mcshane 2008). Empirical evidence does suggest that most entrepreneurs avoid high risk situations as well as low risk situation. They actually settle for moderate risk taking (Sandberg 1992).Risks are rationally assessed and evaluated before committing resources especially long term profits ( Morns \& Kierstko 2002, Hirlovanyi and Szaboq 2006a).

Organisational innovativeness situates the organization in terms of being supportive and amenable to innovation as regards, developing new products of processes, developing new strategic direction and new market horizon (Wang and Ahmed 2004).

For Eisenhardt \& Martin (2000), organizational innovativeness is a concept that refers to the dynamic capabilities of a firm. Organisational innovativeness is a vital source for competitiveness especially to small and medium sized enterprises that are susceptible to crowding out by largely resourced and equipped competitors $\left(\mathrm{O}^{\prime}\right.$ ' Regan and Ghobadian 2005). It is assumed that organizational innovativeness is predicated on various organizational factors (Subramanian 1996, Subramanian and Nihakanta 1996). Evidence suggest that organizational innovativeness increases organizational performance (Bearer and Prince 2002; Hult et al 2004; Calantone et al 2002). However Bash (2004) suggests that the aspiration and indeed the background of the owners of the business affect the tendency to innovate. The extent to which entrepreneurship serves as a creative and innovative act is dependent on the ability of the entrepreneur to add value to that of the individual and the community by perceiving and capturing opportunities (Legge and Hindle 1997, Johnson 2001).

Market orientation has also been said to influence degree of entrepreneurship. It has been opined that new product creation depends on the extent and nature of its market orientation (Hurley and Hult 1998, Tyler and Gnyawali 2002; Frambach et al 2003; Prabhu and Verhallen 2003, Alughene -Gima 1995, 1996)

An enterprise, keen on entrepreneurship and through learning, discovers, learns and applies the knowledge learnt which enables it to adapt to changing circumstances. Obviously, it is through such knowledge and ability to adapt that helps enterprises discover opportunities for success and take advantage of them. Support for this view comes 
from Lorange (1994) who opines that the essential element of organisational learning is the willingness to apply new knowledge. Entrepreneurship involves learning process and an ability to cope with problems and to learn from those problems. Abulum to learn from experience involves the concept of double loop learning. It is a process of learning "how to learn" (Pedler et al 1991). The interaction between learning and entrepreneurship process is highlighted by Levinthal (1996). Learning better from experience, implies bringing knowledge, skills, value and attitude together to interact upon the learning process, it therefore, fundamentally demands an action learning approach. (Gibb 1997)

Organisational learning has come to assume critical importance in modern management literature. It has indeed come to be one of the most promising concepts in strategic management since the late 1980's and has been linked with other key constructs such as innovation (Skerlavaj and Dimovski 2006; Nolas 2006; Huber, 1996) Empirical evidence suggests that many authors and theorists see organizational learning as a basis for sustainable competitive advantage (Fiol and Lyles 19856; Grieves 2000; Epstein and Roy 1977; Garrratt 1987; Kiechel 1990, Senge 1990, Marquardt 2002) are cited by Retna 2007. Cyert and March 1963 have posited that organizational learning be used as a basis for decision making within the firm. The importance is of organizational learning process has been highlighted by various authors including Dodgson 1993; Huber 1991; Daft \& Weick 1984). The concept of shared understanding and mutual adjustment takes place through continual, conversation among members of enterprise community as well as shared practice, (Simons, Seely Brown and Dugund, Weick and Roberts all cited in Crossan et al 1999). Various sources of learning have been identified and this past experience of others (Covington 1985; March \& Olsen 1976; Hurber 1991; Jenseb 1978; Cohen and Leninthal 1989; Iwai 1984). Sources also include thinking experimentation and knowledge recombination (Weick 1979, Sunderlands and Stablein 1987, Comfort 1985, Kogul and Zander 1992; Huber 1991). Indeed the sources can give fillip to learning or supply the ingredients which afford organizations opportunity for ideas and adjustments. The learning approach to entrepreneurships may indeed be the most promising means available to organisations (small and medium) that are willing to increase their strategic ability through the embellishment of creative agenda of business development and opportunities. It is now an accepted fact that there is a clear link between executive education especially for small and medium scale organizations and the companies' ability to meet contemporary and future challenge (Lorange, 1995).

Having reviewed some of the existing literature it may not be out of place to look at the theoretical background.

\section{Theoretical Background}

Various theories have been developed to explain the concept of entrepreneurship and entrepreneurial phenomenon. The social - cultural theory conceptualizes entrepreneurship as having a social role while entrepreneurial development as a function of the firm of the society and characteristics of the culture (Collins and Mone 1970, Stinchombe, 1965). It highlights the role of the socio-cultural environment which provides business ideas, funds, pertinent information and by so doing influences the emergence and behavior as well as performance of entrepreneurs (Ogundele 2000, Bowen and Steyaert, 1990; Stevenson and Sahlman 1990, Carland et al 1984.

Economic theory conceives an entrepreneur as a man who takes advantage of business opportunities discovered. The theory observes that the entrepreneur takes advantages of scarce resources and uses them as well as economic incentives available in the market. Proponents of this theory include (Kilby 1965, Singh 1986; Drucker 1985 and Schumpeter Cole 1959; Rostow 1985 have emphasized on the historical antecedents and other variables on the behaviour, emergence and performance of entrepreneurs.

The psychological approach looks at the personality traits of entrepreneurs which contribute to achievement of goals. Such traits according Winter 1973; Welsh and White 1981; Mc Cleland 1961, need for accomplishment, single mindedness, power as well as other. The educational theory takes the view that level of education enables entrepreneurs to be broadminded and equips them with the ability to understand, organize and coordinate activities more effectively (Singh 1986; Aluko 1983; Akeredolu 1975, Brown and Hirsch 1986) Other theories include experiential theory (Oguntoye 1987; lessem 1983; Obikoya 1995, motivation theory, Tushman and Nelson 1990 Amit et al 1993.

\section{Methodology}

\subsection{Research Design}

For this study, a survey design was adopted which measured two variables independent are dependent variables. The independent variable is entrepreneurial orientation which is measured by three sub variables (risk taking behavior, proactiveness and competitive aggressiveness) while the dependent variable is organizational learning 


\subsection{Sample Size and Data Collection}

The study was carried out in a manufacturing firm in Nigeria. The study was conducted at Unilever, Nigeria PLC. Questionnaire was designed and administered on two hundred and fifty staff of the firm compromising management staff and senior staff at different levels of the organization. Out of 250 questionnaires, 200 were retrieved and found to be usable for further analysis. The data was collected through questionnaire for the purpose accurate and reliable information. The sample size of 250 was drawn using stratified sampling technique

\subsection{Research Instruments}

Questionnaire was used as the instrument for the research. The questionnaire was divided into three sections A, B, C. Section A deals with the demographic data while section B measures entrepreneurial orientation and C concentrates on organizational learning.

The entrepreneurial orientation is 15 item scale adapted from scale developed by Chung Chi (2011) with likert scale scoring format ranging from strongly agree (7) to strongly disagree (1). Three items measured risk taking, three measured proactiveness and competitive aggressiveness was measured by three items.

Furthermore, organizational learning was measured in section $\mathrm{F}$ which has a twenty five item scale. The items measured under organizational learning are knowledge acquisition, knowledge distribution, knowledge interpretation and organizational memory. This is a twenty five item scale using a items 5 point likert scoring format which ranges from strongly disagree 1 to strongly Agree 5.The scale is designed in a way that the first series items deal with knowledge acquisition items while $8-12$ measure knowledge distribution while items $13-17$ measure knowledge interpretation while item $18-25$ measure organizational memory. Organisational learning scale is bases on the work of Lopez et al. These scales have reliability Cronobach alpha values of $0.77,0.77$, and 0.84 respectively.

\subsection{Reliability and Validity of the Instruments}

A nevali exercise was carried on the instruments and cronobach alpha reliability coefficient gave the following results entrepreneurial orientation $=.68$ and organizational learning $=.76$.

\section{Study Hypotheses}

Certain hypotheses were formulated and tested during the study. They include the following

1. There is a significant relationships between risk taking and organizational learning

2. There is a significant relationships between proactiveness and organizational

3. Risk taking, proactiveness, competitive aggressiveness will jointly and independently predict organizational learning.

4. There is main and interactive effect of risk taking and proactiveness on organizational learning

5. There is a significant relationship between competitive aggressiveness and organizational learning.

\section{Data Presentation, Analysis and Interpretation}

Descriptive Statistics of Demographics of Respondents

Table 1. Shows descriptive statistics of demographic

\begin{tabular}{|c|c|c|}
\hline \multicolumn{3}{|c|}{ Sex of Respondents } \\
\hline & Frequency & Percentage \\
\hline Valid Male & 85 & 45.2 \\
\hline Female & 103 & 54.8 \\
\hline Total & 188 & 100.0 \\
\hline \multicolumn{3}{|c|}{ Educational Background of Respondents } \\
\hline & Frequency & Percentage \\
\hline Postgraduate & 95 & 50.5 \\
\hline B.Sc/HND & 26 & 13.8 \\
\hline OND/NCE & 36 & 19.1 \\
\hline $\begin{array}{l}\text { First School Leaving } \\
\text { Certificate }\end{array}$ & 16 & 8.5 \\
\hline Total & 188 & 100.0 \\
\hline \multicolumn{3}{|c|}{ Working Cadre of Respondents } \\
\hline
\end{tabular}




\begin{tabular}{llll}
\hline & & Frequency & Percentage \\
\hline Valid & Management Staff & 111 & 59.0 \\
\hline Senior Staff & 49 & 26.1 \\
\hline Junior Staff & 28 & 26.1 \\
\hline Total & 188 & 100.0 \\
\hline & & Marital Status of Respondents & \\
\hline & & Frequency & Percentage \\
\hline Valid & Married & 84 & 44.7 \\
\hline Single & 64 & 34.0 \\
\hline Divorced & 12 & 6.4 \\
\hline Separated & 28 & 14.9 \\
\hline Total & 188 & 100.0 \\
\hline & & Age of Respondents & \\
\hline Valid & Frequency & Percentage' \\
\hline & 31 & 16.5 \\
\hline 18-25years & 43 & 22.9 \\
\hline 26-35years & 74 & 39.4 \\
\hline 36-45years & 15 & 8.0 \\
\hline 46-55years & 25 & 13.3 \\
\hline 51 and above & 188 & 100.0 \\
\hline Total & Department of Respondents & \\
\hline Valid & Frequency & Percentage' \\
\hline Sales & 21 & 11.2 \\
\hline Marketing & 51 & 27.1 \\
\hline Store/Purchasing & 24 & 12.8 \\
\hline Personnel & 62 & 33.0 \\
\hline Accounting & 14 & 7.4 \\
\hline Production & 16 & 8.5 \\
\hline Total & 188 & 100.0 \\
\hline
\end{tabular}

Source: field survey, 2013

Table 1 indicates the frequency and percentage analysis of the data. The table shows that out of 188 respondents $85(45.2 \%)$ of them are male while $103(54.8 \%)$ are female. The reason why there are more female than male could be due to the nature of the products which involves packing products into cartons. The table equally shows the age distribution of the respondents; 31(16.5\%) of them fall between 18-25years; $43(22.9 \%)$ are between 26-35years, 74(39.4\%) are within age range 36-45years, $15(8.0 \%)$ fall within age range 46-55years while $25(13.3 \%)$ are from 56years and above. The result indicates a reasonable age distribution pattern which makes for continuity and stability in activities.

Table 1 indicates the marital status of the respondents. From the table $64(34.0 \%)$ are single, $84(44.7 \%)$ are married; $12(6.4 \%)$ are divorced while $28(14.9 \%)$ are separated.

The table shows the educational qualifications of the respondents. It can be observed from the table that $95(50.5 \%)$ of the respondents have postgraduate qualification, 26(13.8\%) are graduates that have Higher National Diploma Certificates; 36(19.1\%) have Ordinary National Diploma or National Certificate of Education (NCE); 15(8.0\%) possess secondary certificate while $16(8.5 \%)$ have first school leaving certificate. The result appears to indicate that this organization attaches importance to qualified personnel. The presence of such personnel no doubt would contribute to quality decisions which could translate to quality service.

Table 1 shows that out of the respondents 111(59.0\%) are management, 49(26.1\%) are senior staff while $25(14.9 \%)$ are junior staff. This is a surprising result because ordinarily, those in management positions in Nigerian organizations are indifferent to filling questionnaires.

Table 1 also indicates distribution of respondents by departments. The table shows that $21(11.2 \%)$ are in the sales department; 51(27.1\%) in store/purchasing; $14(7.4 \%)$ in accounting department; $62(33.0 \%)$ in personnel while $16(8.5 \%)$ are in production department. It is not surprising that majority of the respondents are from personnel 
department because by the nature of their job they are amenable to filling up questionnaires than other people from other departments.

\section{Testing the Hypotheses}

Multiple regression analysis was carried to ascertain the joint effects on the variables while Pearson's correlation analysis was carried to test hypotheses 2-4.

Hypothesis 1 - Risk taking behavior, proactiveness, competitive aggressiveness will jointly and independently predict organizational learning.

Table 2. Showing the joint effect of independent variables (risk-taking behavior, proactiveness and competitive aggressiveness) on organizational learning

\begin{tabular}{lllllllll}
\hline Variables & F-ratio & $\begin{array}{l}\text { Sig. of } \\
\text { P. }\end{array}$ & $\mathrm{R}$ & $\mathrm{R}^{2}$ & Adjusted R $^{2}$ & $\beta$ & $\mathrm{T}$ & Probability \\
\hline Risk taking & 1.926 & 0.000 & 0.174 & 0.030 & 0.015 & .075 & 3.05 & 0.000 \\
Proactiveness & & & & & & .524 & 1.489 & 0.000 \\
& & & & & & & & \\
Competitive & & & & & & .093 & .213 & .000 \\
Aggressiveness & & & & & & & & \\
\hline
\end{tabular}

Table 3. Showing the independent effect of risk taking on organizational learning

\begin{tabular}{lllllllll}
\hline Variables & F-ratio & $\begin{array}{l}\text { Sig. of } \\
\text { P. }\end{array}$ & $\mathrm{R}$ & $\mathrm{R}^{2}$ & Adjusted R $^{2}$ & $\beta$ & $\mathrm{T}$ & Probability \\
\hline Risk taking & 1.998 & 0.000 & 0.103 & 0.011 & 0.005 & 0.346 & 1.413 & 0.000 \\
\hline
\end{tabular}

The result on Table 3 above indicates that the result was significant with $\mathrm{F}(1.187)=1.998$. The $\mathrm{R}^{2}$ shows that risk taking accounts for about $1 \%$ in the variation on organizational learning. The result from the coefficient analysis shows that there exists a positive relationship between risk -taking and organizational learning. Since the prediction is low the hypothesis is accepted.

Table 4. Showing the effect of proactiveness on organizational learning

\begin{tabular}{lllllllll}
\hline Variables & F-ratio & $\begin{array}{l}\text { Sig. of } \\
\text { P. }\end{array}$ & $\mathrm{R}$ & $\mathrm{R}^{2}$ & Adjusted R $^{2}$ & $\beta$ & $\mathrm{T}$ & Probability \\
\hline Proactiveness & 5.728 & 0.000 & 0.173 & 0.030 & 0.025 & 0.064 & 2.393 & 0.000 \\
& & & & & & & & \\
\hline
\end{tabular}

Table 4 above shows that the result was significant with $\mathrm{F}(1.187)=5.728, \mathrm{R}=0.173 ; \mathrm{R}^{2}=0.030$ ' Adj. $\mathrm{R}^{2}=.025$. The $\mathrm{R}^{2}$ indicates that proactiveness accounts for about $3 \%$ in the variation on organizational learning. The result from the coefficient table shows that there is a positive relationship between proactiveness and organizational learning. This shows a low prediction of proactiveness on organizational learning.

Table 5. Showing the effect of competitive aggressiveness on organizational learning

\begin{tabular}{lllllllll}
\hline Variables & F-ratio & $\begin{array}{l}\text { Sig. of } \\
\text { P. }\end{array}$ & $\mathrm{R}$ & $\mathrm{R}^{2}$ & Adjusted $^{2}$ & $\beta$ & $\mathrm{T}$ & Probability \\
\hline $\begin{array}{l}\text { competitive } \\
\text { aggressiveness }\end{array}$ & 1.794 & 0.000 & 0.098 & 0.010 & 0.004 & 0.401 & 1.339 & 0.000 \\
\hline
\end{tabular}

Table 5 indicates that the result is significant with $\mathrm{F}(1.187)=1.794$; The $\mathrm{R}^{2}=0.010$ shows that competitive aggressiveness accounts for about $1 \%$ in the variation on organizational learning. The result from the coefficient table shows that there is a positive relationship between aggressiveness and organizational learning. Though the prediction of competitive aggressiveness is low yet, the hypothesis is accepted.

Hypothesis II - There will be a significant relationship between risk taking behavior and organizational learning. 
Table 6. Summary of Pearson's correlation between risk taking of behavior and organizational learning

\begin{tabular}{llllllll}
\hline Variables & Mean & $\begin{array}{l}\text { Standard } \\
\text { deviation }\end{array}$ & $\mathrm{N}$ & $\mathrm{R}$ & $\mathrm{P}$ & \multicolumn{2}{l}{ Remark } \\
\hline Risk taking & 11.4149 & 3.55976 & 188 & & 0.01 & $\begin{array}{l}\text { Significant } \\
1 \%\end{array}$ \\
$\begin{array}{l}\text { Organizational } \\
\text { Learning }\end{array}$ & 80.1489 & 11.95532 & & 0.103 & & & \\
\hline
\end{tabular}

The above result on Table 6 indicates that the mean value of 11.4149 for risk taking and 80.1489 for organizational learning falls within the minimum and maximum values of 5.00 and 20.00 and 58.00 and 116.00 . The result also shows a low standard deviation of 3.55976 and 11.95532. However, the result from the correlation table indicates that correlation is significant at the 0.01 level with a 2 tail test. The result indicates $\mathrm{P}<0.05$ since $\mathrm{P}=0.01$ hence it is significant at $5 \%$. On the basis of the outcome of an analysis, it can be concluded that there is a significant relationship between risk taking and organizational learning. The hypothesis is therefore accepted

Hypothesis III - There will be a significant relationship between proactiveness and organizational learning

Table 7. Summary of Pearson's correlation between proactiveness and organizational learning

\begin{tabular}{llllllll}
\hline Variables & Mean & $\begin{array}{l}\text { Standard } \\
\text { deviation }\end{array}$ & $\mathrm{N}$ & $\mathrm{R}$ & $\mathrm{P}$ & \multicolumn{2}{l}{ Remark } \\
\hline Proactiveness & 12.5106 & 3.42293 & 188 & & 0.01 & $\begin{array}{l}\text { Significant } \\
1 \%\end{array}$ \\
$\begin{array}{l}\text { Organizational } \\
\text { Learning }\end{array}$ & 80.1489 & 11.95532 & & 0.173 & & & \\
\hline
\end{tabular}

The above result shows that the mean value of 12.5106 for proactiveness and 80.1489 for organizational learning falls with the minimum and maximum values of 6.00 and 70.00 and 58.00 and 116.00

The result also indicates a low standard deviation of 3.42293 and 11.95532. However, the result from the correlation table indicates that correlation is significant at the 0.01 level with a 2 tail test. The result also indicates $\mathrm{P}<0.05$ since $\mathrm{P}=0.01$, hence, it is significant at $5 \%$ on the basis of the outcome of the analysis, it can be concluded that there is a significant relationships between proactiveness and organizational learning. The hypothesis is therefore, accepted

Hypothesis IV - There will be a significant relationship between competitive aggressiveness and organizational learning.

Table 8. Summary of Pearson's correlation between competitive aggressiveness and organizational learning

\begin{tabular}{llllllll}
\hline Variables & Mean & $\begin{array}{l}\text { Standard } \\
\text { deviation }\end{array}$ & N & R & P & Remark \\
\hline $\begin{array}{l}\text { competitive } \\
\text { aggressiveness }\end{array}$ & 11.4894 & 2.91683 & 188 & & 0.01 & $\begin{array}{l}\text { Significant at } \\
1 \%\end{array}$ \\
$\begin{array}{l}\text { Organizational } \\
\text { Learning }\end{array}$ & 80.1489 & 11.95532 & & 0.398 & & \\
\hline
\end{tabular}

From Table 8, it can be observed that the mean value of 11.4894 for competitive aggressiveness and 80.1489 for organizational learning falls within the minimum and maximum values of 6.00 and 17.00 and 58.00 and 116.00 . The result also indicates a low standard deviation of 2.91683 and 11.95532. The result from the correlate table however indicate that correlation is significant at the level of 0.01 with a 2 tail test. The result also shows $\mathrm{P}<0.05$ since $\mathrm{P}=$ 0.01 ; hence, it is significant at $5 \%$. On the basis the outcome of the analysis, it is concluded that there is a significant relationship between competitive aggressiveness and organizational learning. The hypothesis is therefore accepted.

Hypothesis $\mathrm{V}$-There will be main and interactive effect of risk taking behavior and proactiveness on organizational learning. 
Table 9. Showing the main and interactive effect of risk-taking behavior and proactiveness on organizational learning

\begin{tabular}{lllllllll}
\hline Variables & F-ratio & $\begin{array}{l}\text { Sig. of } \\
\text { P. }\end{array}$ & $\mathrm{R}$ & $\mathrm{R}^{2}$ & Adjusted R $^{2}$ & $\beta$ & $\mathrm{T}$ & Probability \\
\hline Risk taking & 9.671 & 0.000 & 0.103 & 0.011 & 0.005 & 0.346 & 1.413 & 0.000 \\
Proactiveness & & & & & & 0.604 & 2.393 & \\
\hline
\end{tabular}

It is observable from the table above that risk taking and proactiveness have main and interactive effect on organizational learning. This result appears significant with $\mathrm{F}(2.186)=9.6>1$ with $\mathrm{P}<0.01$. The result shows that it is significant at $1 \%$. The $\mathrm{R}$ value of approximately $0.103, \mathrm{R}^{2}=11$ and of approximately 0.005 indicate that the independent variables jointly account for a variation of about $10 \%$ of the dependent variable indicating that both risk taking and proactiveness account for about $10 \%$ in the variation of organizational learning. Based on the coefficient result from the value of $\beta$, the result indicates that, $1 \%$ increase in risk taking will lead to about $10 \%$ rise in the organizational learning while a $1 \%$ rise in proactiveness will lead to about $17 \%$ increase in organizational learning. Furthermore, the result from the values of 1.413 and $2.393 \mathrm{P}>0.1$ indicate that while risk taking is significantly determined organizational learning, proactiveness tends to improve it, though not a significant factor that determines organizational learning. On the basis of the result, the hypothesis is accepted.

\section{Conclusion}

The results of the study have shown a clear relationship between entrepreneurial orientation and organizational learning. Entrepreneurship is the process of initiating a business venture, organizing the necessary resources and assuming the associated risks / rewards (Kuratko and Hodgetts 1998). The result of this study tends to support the above view because risk taking of behavior and the consequent organizational learning are two possible ingredients in organizational growth and survival. The result of the study does indicate that proactiveness and competitive aggressiveness impact in organizational learning with resultant effect on organizational growth and performance. To survive in competitive market firms must be entrepreneurial in action and must align decisions consistent with entrepreneurial behavior. Hule and Mcshane (2008). The result of the study indicates that organizations must learn and with the knowledge and skills from such learning adjust their strategies to take advantage of emerging opportunities. On the whole, the result of the study indicates that entrepreneurship orientation (represented by risk taking, behavior, proactiveness and competitive aggressiveness) is very critical and essential in tackling todays volatile and unpredictable business environment. Organisational learning is the oil that lubricates the wheel of the enterprise ability to compete effectively and efficiently and by so doing may experience desired goal achievement and growth

\section{Recommendations}

1. Given the increasing volatility of enterprise operating environment it is recommended that business organizations in Nigeria should increase their coping ability through continual organizational learning and entrepreneurial innovativeness.

2. Organisations should ensure that staff possess required line competencies

3. Business organizations should continually put into effect experiences learnt from past challenges in order to be effectively proactive and responsive.

\section{References}

Agyric, C., \& Schon, D. (1996). organizational learning, method and practice. Addison-Wesley publishing compulsory, pp.20-24.

Akeredolu, Ale, E.O. (1975). Underdevelopment of indigenous entrepreneurship in Nigeria. Ibadan University press.

Aluko, S. (1983). Research in entrepreneurship development in Nigeria. In U.Udo. Aka (Eds.), Management Education for National Development (pp 86-106). Centre for management. Lagos.

Amur, R., Gloslen, L., \& Muller, E. (1993). Challenges to theory development in entrepreneurship research. Journal of Management Studies, 30(5), 815-834. http://dx.doi.org/10.1111/j.1467-6486.1993.tb00327.x

Balasubramaman, V. (2004). Organizational learning and Information systems. Retrieved from onlinehttp//www.epapyrus.com/personal/orglin/origin/tmb 
Bartlett, C.A., \& Ghoshal, S. (2000). Transitional Management ( ${ }^{\text {rd }}$ ed.). Mc Graw-Hue, High Education, pp.782-788.

Bearer, G., \& Prince, C. (2002). Innovation, entrepreneurship and competitive advantage in the entrepreneurial venture. Journal of small Business and Enterprises Dev, 8(2), 157-75.

Boettkap, \&Onye, C. (2002). Entrepreneurship and Development: "Cause or consequence" Global Prosperity Initiative wp6. George Mason University.

Bornstein, D. (2005). How to change the World social entrepreneurs and the power of new ideas. Penquin Books New Delhi.

Bowen, R., \& Hursah. (1956). The female entrepreneur: a career development perspective. Academy of Management Review, 11(2), 393-407.

Bowen, R., \& Skyaerr, C. (1990). Constructing organisational texture in young entrepreneurial firms.

Calantone, R.J.S., Tameric, \& Yushan Zhao. (2002). Learning orientation from innovation capability and from performance industrial marketing Management. Journal of Management Studies, 31(6), 637-649.

Cangelosi, V.E., \& Dill, W.R. (1965). Organisational learning: observations towards a theory. Administrative science Quantity, 10(2), 175-203. http://dx.doi.org/10.2307/2391412

Carland, J.W., Hoy, F., Boulton, W.R., \& Carland, J.C. (1984). Differentiating entrepreneurs from small business owners: A conceptualization. Academy of Management Review, 9(2), 354-539.

Castaneda, D.I., \& RIDs, M.F. (2007). From individual learning to organisational learning. The Electronic Journal of knowledge Management, 5(4), 363-372.

Chang Chi R.D. (2012). The influence of entrepreneurial orientation on Technology commercialization. African Journal of Business Management, 6, 370-387.

Chen, G. (2005). An organisational learning model based on western and Chinese Management thoughts and practices. Management Decision 43(4), 479-500. http://dx.doi.org/10.1108/00251740510593503

Chevevton, P. (2006). Global Account Management. Cambridge press L mason.

Cole, A.H. (1959). Business enterprises in its settings. Cambridge, Harrow University Press.

Collens, O.F., \& Moone, D.G. (1970). Organisation Mallers. New York: Applaton Century, Craft Menedity Corporation

Cope, J. (2003). Entrepreneurial learning and learning and critical reflections, discontinuous events as triggers for higher level learning. Management Learning, 14(4), 421-450.

Corbitt, A.C. (2005). Experimental learning within the process of opportunity identification and exploitation. Entrepreneurship Theory \& practices, 29(4), 473-492. http://dx.doi.org/10.1111/j.1540-6520.2005.00094.x

Cotis, J. (2007). Entrepreneurship as engine of growth : evidence and policy Challenges. Global Entrepreneurship Monitor (GEM). Retrieved from www.oecd.org/dataoecd /4/51/3803895

Coussins, C. (1999). 11 points plan for Business on the Internet. Hullalhan, Glasgow.

Crossan, M. L., \& H. White, R. (1999). An organisational learning frame work: from intuition to institution. Academy of Management Review, 24(3), 522-537.

Curran, J., \& Stanworth, J. (1989). Education and training for enterprise. Some problems of classification, evaluation, policy and research. International small Business Journal, 7(2), 11-22. http://dx.doi.org/10.1177/026624268900700201

Cybert, R.M., \& March, J.G. (1963). A behavioural Theory of the firm. Englewood, Clyts, W.J, prentice- hall.

Daft, R.L., \& Maric, D. (1998). Understanding Management. The Dryden Press, pp.165-183.

Davison, P., \& Honig, B. (2002). The role of social and human capital among nascent entrepreneurs. Journal of Business Ventures, 18(3).

De Geus, A.P. (1988). Planning as learning. Harran Business Review, 88(2), 70-74.

Dealons, D., \& Fred, M. (2009). Entrepreneurship and small firm ( $5^{\text {th }}$ ed.). Mc Graw, Hill Education. 
Dees, J.G. (2001). The meaning of "social entrepreneurship". Online paper available or waves. Fuqua. Duke. Retrieved from edu/centres/case/documents/dees/S.E.pat

Department of Trade \& Industry (DTI) UK. (2002). Social Enterprise: A Strategy for success. Easterby.

Dodgson, M. (1993). Organisational, learning. The Academy of Management Review, 10, 803-813.

Drucker, P.F. (1985). Innovational and Entrepreneurship: practice and Principle. London: William Heinmann Ltd.

Eisen hardt, K.M., \& Jettrey, A. Martins. (2000). Dynamic capability what are they? Strategy Management Journal, 21(10-11), 1105-21.

Englewood Cliff, Prentice Hall Inc. Kh, \& walla, P.N. (1977). Some Top Management Styles, Their context and performance. Organisation \& Administrative sachcas, 7(4), 21-51.

Fiol, M., \& Lyles, M. (1985). Organisational learning. The Academy of Management Review, 503-513.

Gibb, A. (1997). Small forms' training and competitiveness; Building upon the small business as a learning organization. International Small Business Journal, 15(3), 13-25. http://dx.doi.org/10.1177/0266242697153001

Global entrepreneurship Monitor (GEM) 2006 Exclusive Report. Babson College, Kauffman foundation and London Business School.

Goli, L., \& Rasheed, A.M. (1997). Rational Decision-making and form performance: The moderating Role of $\begin{array}{llll}\text { Environment. } & \text { Strategic } & \text { Management } & \text { Journal, }\end{array}$ http://dx.doi.org/10.1002/(SICI)1097-0266(199708)18:7<583::AID-SMJ907>3.0.CO;2-Z

Goven, J.G., \& Slevin, D.P. (1991). A conceptual model of Entrepreneurship as from behavior. Entrepreneurship Theory on practice, 16(1), 7-25.

Harris, J. R. (1968). Nigeria enterprise in the printing industry. Nigeria Journal of social and Economy Studies, 10(2), 215-227.

Hill, L.W.L., \& Meshane, S.L. (2008). Principle of Management. Mc Graw. Hill, lvwin

Hockerts, K. (2006). Entrepreneurial opportunity in social purpose business venture. In JMair, J, Robertson and K. Hockerts (Eds.), Social entrepreneurship. Palgrave, Mcmillan, London.

Huber, G. (1991). Organisational learning. The Academy of Management Review, 14(3), 375-394.

Huer, G., Thomas, M., Robert, F., \& Gary A. Kniger. (2004). Innovativeness: Its antecedents and impact on Business

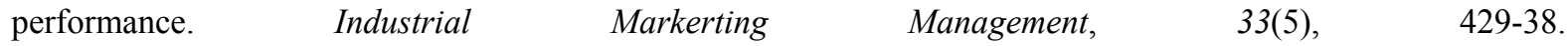
http://dx.doi.org/10.1016/j.indmarman.2003.08.015

Hurley, R.F., \& Huer, T.M. (1998). Innovation, Market orientation, and empirical examination. Journal of Marketing, 62(3), 42-54. http://dx.doi.org/10.2307/1251742

Kao, J.J. (1989). Entrepreneurship, creativity and organisation, text, cases and readings. Englewood Cliff, prentice Hall Inc.

Kilby, P. (1965). African enterprise: The Nigerian Break Industry. The Hoover Institution on war, Revolution \& Peace, Standard University.

Kuratko, D.F., \& Hogertts, R.M. (1998). Entrepreneurship: A contemporary Approach. Chicago; The Dryden Press, pp.165-183.

Lessem, R. (1983). The art of Entrepreneurship. Journal of General Management, 8(3), 34-49.

Levinthal, D. (1996). Learning \& Schumperian Dynamics. In G Dosi and F Malerba (Eds.), Organisation and strategic in Evolution of Enterprise. Mcmillan, Honton.

Lieberman, M., \&Montgomery, D. (1988). First mover Advantages. Strategic Management Journal, 9, 41-58. http://dx.doi.org/10.1002/smj.4250090706

Lovange, Peter. (1955, Nov.). Creating A learning Partnership: A key to competitive Advantages. Perspective for Managers.

Lumpkin, G.T., \& Dees, G.G. (2001). Linking two dimensions of entrepreneurial orientation to firm performance. The moderating role of or environment and industry like Cycle. Journal of Business Venturing, 16, 429-51. http://dx.doi.org/10.1016/S0883-9026(00)00048-3 
Manolova, T.S., \& Yan, A. (2002). Institutional constraints and entrepreneurial responses in a transforming economy: the case of Bulgaria. International Small Business Journal, 20(2), 163-184. http://dx.doi.org/10.1177/0266242602202003

Mclelland, D. C (1960). The Achieving Society. D. Van Nostrand Company, Inc, Princeton; NJ.

Miller, D. (1983). The Correlates of Entrepreneurship in three types of Firms. Management Science, 29(7), 70 -79. http://dx.doi.org/10.1287/mnsc.29.7.770

Miller, D. (1988). Relating Porter's Business Strategies to Environment and Structure: Analysis and Performance Implications. Academy of Management Journal, 31(2), 280-308. http://dx.doi.org/10.2307/256549

Millert, D., \& Frieson, P.H. (1982). Innovation in Conservative and entrepreneurial firms: Two momentums. Strategic Management Journal, 3(1), 1-25. http://dx.doi.org/10.1002/smj.4250030102

Nicholls, A., \& Cho, A. (2006). Social entrepreneurship the structuration of field. In A Nicholls (Ed.), Social entrepreneurship: new models (pp.99-118). Oxford University Press.

Nolas, S. (2006). Learning AS Support for Organisational innovation: Possibilities and Limitations. World Futures, 62, 240-260 (1556-1844 0n line) Routledge Taylor \& Francis Group.

O.E.C.D. (2005). Entrepreneurship and Small and Medium Enterprise. Outlook, OECD, Paris pp.16.

O'Regan, N., \& Gbobadian, A. (2005). Innovation in SMEs: the impact of strategies orientation and environmental perceptions. International Journal of Productivity and Performance Management, 543(121), 81-97. http://dx.doi.org/10.1108/17410400510576595

Obikoya, O. (1995). Small and medium enterprise (SMEs) in Nigeria: Problems and Prospects. In A.T Ojo (Ed.), Management of small and medium enterprises in Nigeria (pp.246-256). Ikeja, Pumark Nigeria Ltd.

Ogundele, O.J.K. (2000). Determinants of Entrepreneurial emergence, behaviour and performance in Nigeria.

Ogundele, O.J.K. (2007). Entrepreneurship Development Corporate Governance and Small Business Management. Molofin Nominees Lagos, Nigeria

Okongwu, D. Saleh, \& A. Usman (Eds). Unpublished Doctrinal Dissertation Lagos, University of Lagos, Nigeria Fundamental Issues in Entrepreneurship, Appex Books Ltd, Lagos, Nigeria.

Pedler, M., Burgoyne, J., \& Boydele, T. (1991). The Learning Company: A strategy of substantial Development. McGraw hill, Maiden Head.

Politis, D. (2005). The process of entrepreneurial learning: a conceptual framework. Entrepreneurial Theory and Practice, 29(4), 399-424. http://dx.doi.org/10.1111/j.1540-6520.2005.00091.x

Porter, M. (1990). The Competitive Advantage of Nations. Free Press, New York.

Rae, D., \& Carswell, M. (2001). Towards a conceptual understanding of entrepreneurial learning. Journal of Small Business and Enterprise Development, 8(2), 150-158. http://dx.doi.org/10.1108/EUM0000000006816

Retna, K. (2007). The Learning Organisation: L A Schools journey towards critical and creative thinking: The Asia. Pacific Education Researcher, 16(2), 127-142.

Reynolds, P.D., \& White, S.B. (1997). The Entrepreneurial Process: Economic Growth, men, women and minorities. Quorum, WestPoint, CT.

Schumpeter, J. (1934). The Theory of Economic Development. Havard, University Press Cambridge M.A.

Seelos, \& Macr, L. (2005). Sustainable Development: how social entrepre4neurs make it happen, IESE. Business School Working Paper n) 611, University of Navarra.

Seely Brown, J., \& Dugund, P. (1991). Organisational learning and communities practice: Towards a unified view of working learning and innovation. Organization Science, 2(1), special issue. http://dx.doi.org/10.1287/orsc.2.1.40

Senge, P.M. (1990). The fifth Discipline: The ark and Practice of the learning organization. Doubleday British Edition 1992. London, Random House.

Sharlen G (1994). Capitalist and Entrepreneurs in ownership managed firms. International Small Business Journal, 12(3), 33-41. http://dx.doi.org/10.1177/0266242694123003 
Simon, D.G., \& Hitt, M.A. (2003). Management Resources: Linking of Unique Resources, Management and Wealth Creation in Family Firms. Entrepreneurial: theory and practice, 27(4), 339-358.

Singh, P.N. (1986). Developing Entrepreneurship for Economic Growth. New Delhi; Vikas, Publishing House, PVt Ltd.

Smith, M., Thorpe, R., \& Lowe, A. (2002). Management Research: An introduction ( $2^{\text {nd }}$ ed.). sage, London.

Stevenson, H.H., \& Jarillo, J.C. (1990). A paradigm of entrepreneurships: entrepreneurial management. Strategic management journal, 11, special issue, 17-27.

Stevenson, H.H., \& Sahlman, N.A. (1990). Entrepreneurial Process. In J Dewurst (Ed.), Small Busines and Entrepreneurship (pp.195 -124). London, Mcmillan.

Stinchombe, A. L. (1965). Social Stucture and Organisatio. In J.G March (Ed.), Hand Book of organization (pp 143-193).

Subramanian, A.X., \& Nilakanta, S. (1996). Organisational Innovativeness: Exploring the relationship between organizational determinants of innovation type of innovation and measures of organizational performance. Omega, 24(6), 631-47. http://dx.doi.org/10.1016/S0305-0483(96)00031-X

TushmaN, M.L., \& Nelson, K.R. (1990). Production: Technology Organisation: Problems and Prospects. In A. T. Ojo (Ed.), Management of Small and Medium Enterprises in Nigeria (pp.246-256).

Waddock, S., \& Post, I. (1991). Social entrepreneur and Catalytic Change. Public Administration Review, 51, 393-401. http://dx.doi.org/10.2307/976408

Wang, C.C., \& Pervaiz, K.A. (2004). The development and validation of the organizational innovativeness construct using confirmatory analysis. European Journal of Innovation Management, 7(4), 303-13. http://dx.doi.org/10.1108/14601060410565056

Weick, K.E. (1979). The social Psychology of Organizing (2nd ed.). London Addison Wesley.

Welsh, J.A., \& White J.F. (1981). Converging on Characteristics of entrepreneurs. In K. H. Vester (Ed.), Frontiers of entrepreneurship research (pp.504 -515). Wesesley Mass, Babson Centre for Entrepreneurial Studies.

Wennekers, S., \& Thurik, R. (1999). Linking entrepreneurship and economic growth. Small Business Economics, 13, 27-55. http://dx.doi.org/10.1023/A:1008063200484

Wiklund, J. (1999). The Sustainability of the entrepreneurial orientation performance relationship. Entrepreneurship: Theory and Practice, 24(1), 37-48.

Wiklund, J., \& Shepherd, D. (2005). Entrepreneurial Orientation and Small Business Performance: A Configurational Approach. Journal of Business Venturing, 20(1), 71-91. http://dx.doi.org/10.1016/j.jbusvent.2004.01.001

Winter, D.G. (1973). The Power Motive. New York: Free Press.

Wyer, Mason, J., \& Theodara, K.N. (2000). Small Business development and the "learning Organisation. International Journal of Entrepreneurial behavior and Research, 6(4), 239-259. http://dx.doi.org/10.1108/13552550010355136

Zahra, S.A. (1993). Environment Corporate Entrepreneurship and Financial Performance: A Taxonomic Approach. Journal of Business Venturing, 8, 319-340. http://dx.doi.org/10.1016/0883-9026(93)90003-N

Zahra, S.A. (1996). Technology Strategy and Financial Performance: Examining the Moderating Role of the Firm's Competitive Environment. Journal of Business Venturing, 11(3), 189-219. http://dx.doi.org/10.1016/0883-9026(96)00001-8

Zhang, M., Macpherson, A., \& Jones, O. (2006). Conceptualizing the learning process in SMEs: Improving Innovation through External Orientation. International Small Business Journal, 24(3), 299 -323. http://dx.doi.org/10.1177/0266242606063434 